\title{
Soil properties, grassland management, and landscape diversity drive the assembly of earthworm communities in temperate grasslands
}

\author{
Kevin HOEFFNER ${ }^{\text {ab }}$ Mathieu SANTONJA ${ }^{\text {ac }}$ Cécile MONARD ${ }^{a}$ Lou BARBE \\ Mathilde LEMOINGa Daniel CLUZEAU ${ }^{a}$
}

a b University of Rennes, CNRS, ECOBIO UMR 6553, Rennes F-35000 (France)

INRAE, AGROCAMPUS OUEST UMR SAS, Rennes F-35000 (France)

Aix Marseille Université, Avignon Université, CNRS, IRD, IMBE, Marseille F-13397 (France)

\section{Abstract}

Earthworms are widespread soil organisms that contribute to a wide range of ecosystem services. As such, it is important to improve our knowledge, still scanty, of the factors that drive the assembly of earthworm communities. The aim of the present study was to conjointly evaluate the effects on the assembly of earthworm communities of i) soil properties (texture, organic matter content, and $\mathrm{pH}$ ), ii) grassland management (grassland age, livestock unit, and type of fertilization), iii) landscape diversity (richness, diversity of surrounding habitats, and grassland plant diversity), and iv) presence of hedgerows. The study was conducted in temperate grasslands of Brittany, France. Earthworms were sampled in 24 grasslands and, in three of these grasslands, they were sampled near a hedgerow or near a ditch (control without a hedgerow). Soil properties explained the larger portion of the variation in the earthworm community parameters compared to grassland management or landscape diversity. The increase in soil organic matter content and $\mathrm{pH}$ were the most favorable factors for earthworm abundance and biomass, in particular for endogeic species. Regarding grassland management, the increase in the livestock unit was the most damaging factor for earthworm communities, in particular for the anecic earthworm biomass and endogeic species richness. Surprisingly, landscape diversity negatively affected the total earthworm abundance and epigeic earthworm biomass, but it was related to an increase in the epi-anecic species. At a finer scale, we also demonstrated that the presence of hedgerows surrounding grasslands enhanced earthworm species richness, especially within the epigeic and anecic ecological categories. This study highlights that the earthworm ecological categories respond specifically to environmental filters; further studies need to be conducted to elucidate the factors that drive the assembly of earthworm communities at this ecological category level. We recommend that policymakers should act on landscape management to favor earthworm diversity in order to improve the ecosystem services they drive. 
Earthworms are widespread soil organisms constituting the most important terrestrial biomass in temperate climate zones (Hole, 1981; Bar-On et al., 2018). They are usually classified into three main ecological categories depending on their physiology, morphology and behaviour: epigeic, anecic and endogeic species (Bouché, 1972, 1977). Briefly, epigeic earthworms live in and consume surface organic matter, anecic earthworms burrow vertical galleries to feed on a mixture of surface and soil organic matter, and endogeic earthworms burrow horizontal galleries to feed on soil organic matter (Bouché and Kretzschmar, 1974; Bouché, 1977; Jégou et al., 1998). Additionally, within the anecic earthworms, epianecic species feed preferentially on fresh surface organic matter (i.e. leaf litter) and are thereby distinguished from strict-anecic species that feed preferentially on humified organic matter already incorporated into the soil (Jégou et al., 1998; Larsen et al., 2016; Hoeffner et al., 2019). Depending on their ecological categories and associated feeding and burrowing behaviour, earthworms contribute to important ecosystem services provided by the soil such as nutrient cycling, water and climate regulation and primary production (Blouin et al., 2013; Bertrand et al., 2015). For example, van Groenigen et al. (2014) reported in a meta-analysis that an increase in crop production was observed in presence of earthworms, this increase ranging from $18 \%$ in presence of epigeic species up to $32 \%$ in presence of anecic species.

Earthworm communities are governed by different environmental filters, including biogeographical history, soil properties, land use and management as well as species interactions within the community (e.g. competition or facilitation; Lavelle, 1983; Curry, 2004; Decaëns et al., 2008). Previous studies focusing on the impact of soil properties on earthworm communities highlighted the key role played by soil $\mathrm{pH}$, soil organic matter content and soil texture (Joschko et al., 2006; Lee, 1985; Decaëns et al., 2008). Other studies focused on the impact of land use on these earthworm communities (Boag et al., 1997; Decaëns et al., 2003, 2008; Cluzeau et al., 2012). For example, Ponge et al. (2013) reported that grasslands exhibited higher anecic earthworm abundance than croplands. In addition, Zaller and Arnone (1999) observed a positive correlation between the density and the biomass of earthworm communities and the plant species richness of grasslands, and in particular for endogeic species. Concerning land management, previous studies reported that ploughing (Chan, 2001; Briones and Schmidt, 2017), pesticide application (Pelosi et al., 2014) and low permanent cover (Vršic, 2011) negatively impact earthworm communities with a response intensity depending on the ecological category considered.

Other studies have been undertaken at a greater scale to evaluate the impact of landscape diversity on earthworm communities within croplands (Vanbergen et al., 2007; Lüscher et al., 2014; Frazão et al., 81 2017). For example, Flohre et al. (2011) observed that the earthworm species richness in croplands 
82 decreased with the percentage of surrounding agricultural fields. Regulska and Kolaczkowska (2015) also

83 reported that a cropland surrounded by a diverse landscape supported a higher earthworm diversity, density

84 and biomass than the same type of cropland surrounded by a simpler landscape. However, the majority of

85 the previous studies did not report effect of landscape diversity on earthworm communities of croplands

86 and vineyards (Kovács-Hostyánszki et al., 2013; Frazão et al., 2017; Buchholz et al., 2017). Moreover, field

87 margins of croplands were reported to exhibit higher abundance and diversity of earthworms than in the

88 croplands itself but, surprisingly, these field margins were not reported to favor earthworm populations of

89 these croplands (Smith et al., 2008; Roarty and Schmidt, 2013; Crittenden et al., 2015). Whether and how

90 earthworms disperse within agricultural landscapes hence remains an unresolved issue.

91 A strong research effort has been done in the past decades to study the earthworm communities of

92 croplands. Grasslands are the largest terrestrial ecosystem in the globe and produce many key ecosystem

93 services, such as carbon storage, soil erosion mitigation or support for pollinators (Costanza et al., 1997;

94 Conant and Paustian, 2002; Werling et al., 2014). The main objective of the present study was to conjointly

95 evaluate the effects of soil properties, grassland management and landscape diversity on the assembly of

96 grassland earthworm communities. Specifically, we hypothesized that the intensity of grassland

97 management would negatively affect earthworm community parameters while the landscape diversity

98 surrounding the grasslands would increase earthworm community parameters. The second objective was to

99 evaluate the effect of hedgerows on these earthworm communities. By increasing the number of available

100 niches, we hypothesized that the presence of a hedgerow in the grassland edge would increase earthworm

101 community parameters (Tews et al., 2004). We conducted the study in an agricultural landscape of Brittany,

102 France. Earthworms were sampled in 24 grasslands and, within three of them, they were oversampled near

103 a hedgerow and near a ditch (control without hedgerow). Several parameters of the earthworm communities

104 were evaluated including (i) the total abundance, total biomass, species richness and species diversity and

105 (ii) the abundance, biomass and richness within each earthworm ecological category.

106

107 MATERIALS AND METHODS

108 Study site

109 The study site covers $10 \mathrm{~km}^{2}$ and is a part of the Long Term Ecological Research (LTER) “Zone

110 Atelier Armorique’', located in Brittany, France (4850’ N, -158’ W). The climate of the area is oceanic

111 with a mean annual temperature of $11.7^{\circ} \mathrm{C}$, a mean annual rainfall of $815.0 \mathrm{~mm}$ and a mean annual relative

112 humidity of 80.9 \% (mean values over the period 2010-2016, data from Météo France). The main soil types

113 encountered are Cambisols (IUSS Working Group, 2015) with high bedrock heterogeneity (granite, soft

114 schist and aeolian loam). Moreover, the study area presents a substantial micro-topography, mainly due to 
115 a high variability of landscape structures (e.g. hedges and ditches as field margins) with a hedge density 116 ranging from 50 to 100 m.ha-1 (Baudry et al., 2000; Thomas et al., 2016). Land use comprises mainly annual 117 crops (corn, wheat, barley) and temporary or permanent grasslands, forest and unmanaged areas.

118 We used ground-truth aerial photos, which were taken every year since 1990, to construct a detailed 119 land-use history for all grasslands, allowing us to precisely determine the age of each grassland. Based on 120 this land-use history and after verification with grassland owners, we selected 24 grasslands ranging from 1 121 to 25 years since the last crop. Among them, three grasslands with an age gradient of 1-, 2- and 7-year-old 122 were selected and oversampled from a hedgerow and a ditch at their surroundings to take into account a 123 specific effect of hedgerow on soil properties (Marshall and Moonen, 2002; Walter et al., 2003).

\section{Earthworm sampling and laboratory analyses}

Earthworms were sampled in 2016 within the 24 grasslands at a $30 \mathrm{~m}$ distance from any grassland edge, and then in the 3 selected grasslands near a ditch and near a hedgerow. For the 3 selected grasslands, we standardized the sampling with 3 sampling points in order to consider 3 replicates with hedgerow (at 1 , 5 and $10 \mathrm{~m}$ from the hedgerow) and 3 replicates without hedgerow (at 1, 5 and $10 \mathrm{~m}$ from the ditch).

Earthworms sampling followed the normalized protocol ISO 23 611-1, that was modified and validated during the RMQS BioDiv program (Cluzeau et al., 2012) combining chemical and physical extractions. Briefly, each earthworm sampling was characterised by a mean of three sub-sampling spaced of $10 \mathrm{~m}$ in line. Earthworm sub-sampling consisted of three waterings of $10 \mathrm{~L}$ with a gradient concentration of formaldehyde $(0.25,0.25$ and $0.4 \%)$ on one square meter. After each watering, earthworms were collected for 15 min. Afterwards, a block of soil $(25 \times 25 \times 20 \mathrm{~cm}$, length $\times$ width $\times$ depth $)$ was excavated within each sub-sampling area and earthworms were hand-sorted. The number of hand-sorted earthworms (HS) was multiplied by 16 to obtain an estimation per square meter. This number was then added to the number of earthworms counted with the formaldehyde extraction (F) to obtain the total number of earthworms per square meter $(\mathrm{FHS})$ : FHS = F + $(16 \times$ HS). Earthworms were fixed and preserved in formaldehyde solution 140 (4\%).

In the laboratory, each earthworm individual was counted, weighed, assigned to a stage of 143 category: epigeic, anecic or endogeic (Bouché, 1972, 1977). Additionally, we distinguished within anecic 144 earthworms, the epi-anecic (genus Lumbricus) from the strict-anecic earthworms (genus Aporrectodea) 145 (Ferrière, 1980; Jégou et al., 1998). For juvenile individuals, identification was first limited to the genus and 146 thereafter they were attributed a species name according to the proportions of sub-adults and adults present 
147 of the same genus on each square meter. Earthworm diversity was analysed through three levels: total

148 species richness, Shannon diversity index and species evenness index.

Environmental filters

We selected three environmental filters to explain earthworm community parameters: soil properties, grassland management and landscape diversity.

Soil properties were characterized by the soil texture, organic matter content and $\mathrm{pH}$ (water). Ten soil samples were randomly collected at $3 \mathrm{~m}$ around the earthworm sub-samplings using a cylindrical soil corer ( $5 \mathrm{~cm}$ diameter $\times 20 \mathrm{~cm}$ depth) in each grassland. These 10 soil samples were pooled and homogenized in order to consider one composite soil sample per grassland and sent to the analytical laboratory of LABOCEA (Combourg, France). Briefly, clay content ranged from 9.5\% to 19.7\%, sand content from $13.3 \%$ to $68.9 \%$, organic matter content from $1.8 \%$ to $5.2 \%$ and soil pH from 5.5 to 6.7 (Supplementary Table S1). using quite similar species sown (Lolium perenne and Trifolium repens or pratensis). In addition, livestock unit per hectare varied from 0 to 4.3. Fertilisation rate was declarative so we used only the distinction between organic and mineral input. based on aerial photos (forest, grassland, crop, hedge, water, building, garden, asphalt area, road). The radius of $100 \mathrm{~m}$ was chosen to reflect the overall low mobility of earthworms (Bardgett et al., 2005; Eijsackers, 2010, 2011). Landscape diversity was characterized by two indexes: total richness of habitats within the radius and Shannon Diversity Index of habitats (hereafter called SHDI). Mapping and analysis were done using the softwares QGis 2.8.1 and FRAGSTATS 4.296. In addition, we characterized the plant community of the 24 grasslands in spring 2015 using 10 quadrats $(1 \times 1 \mathrm{~m})$ evenly distributed in each grassland, characterizing for each plant species its covering percentage. Among the 24 grasslands selected, landscape richness varied from 1 to 7 habitats (maximum number of habitats has never been observed), SHDI from

175 (Supplementary Table S1).

\section{Statistical analysis}

We used multiple linear regression models to test the effects of soil properties (decomposed in clay, sand, organic matter contents and $\mathrm{pH}$ ), grassland management (decomposed in grassland age, livestock unit 
and fertilisation), and landscape diversity (decomposed in landscape richness, SHDI and plant diversity) on all earthworm community parameters (i.e. total abundance and biomass, total diversity indexes, ecological categories abundance and biomass). We constructed a full model comprising all environmental filters, and then we selected the significant environmental filters using a backward stepwise selection procedure that selects the best model using the AIC criterion (Crawley, 2012; stepAIC function of the "MASS” package). We also evaluated the variance inflation factor (VIF) of each variable selected by the previous procedure to test for multicollinearity among environmental filters. We removed all environmental filters that showed a VIF > 5, even if significant from the model. Data met the conditions of normality and homoscedasticity. earthworm communities with and without hedgerow (ditch) using the three sampling points per plot as replicates. We used separated $t$-tests within the three selected grasslands to assess the differences in earthworm abundance, earthworm biomass, and species richness according to the presence or absence of a hedgerow.

Statistical analyses were performed with the R software 3.2.3 (R. Core Team, 2017). Significance

\section{RESULTS} communities

Over the 24 grasslands sampled, the average earthworm abundance and biomass were $517.0 \pm 57$ individual. $\mathrm{m}^{-2}$ and $219.4 \pm 20$ g. $\mathrm{m}^{-2}$, respectively. The mean earthworm species richness was $10.8 \pm 0.3$. Eighteen species belonging to the three ecological categories were identified (Supplementary Table S2). Allolobophora chlorotica and Aporrectodea caliginosa were the most abundant species whereas Eisenia tetraedra, Dendrobaena rubida and Octalasium lacteum were present in one grassland only (Supplementary Table S2).

Higher soil organic matter content increased the total earthworm abundance $(F=5.3, P=0.033$,

Table 1), the endogeic species abundance ( $F=5.7, P=0.028$, Supplementary Table S3) and the endogeic species richness ( $F=5.4, P=0.031$, Supplementary Table S4), while the endogeic species abundance was negatively correlated to the sand content ( $F=6.9, P=0.017$, Supplementary Table S3). In addition the total earthworm abundance and biomass increased when soil $\mathrm{pH}$ was more alkaline $(F=5.0$ and $6.8, P<0.05$, Fig. 1, Table 1) but no category-specific impact was observed with respect to $\mathrm{pH}$ variation.

212 in particular the biomass of anecic species ( $F=9.6, P=0.005$, Fig. 2a, Supplementary Table S5). However, 
213 this negative effect was only confirmed for the biomass of epi-anecic species $(F=4.4, P=0.049$, Fig. $2 \mathrm{~b}$,

214 Supplementary Table S5). The increase in livestock unit also decreased the earthworm species richness, the

215 Shannon diversity index and the species evenness ( $F=2.8$ to 9.6, $P<0.05$, Fig. 2c, Table 1 ), and in particular

216 the endogeic species richness ( $F=9.5, P=0.006$, Supplementary Table S4). Mineral fertilisation enhanced

217 the epigeic species abundance and biomass compared to organic fertilisation $(F=6.6$ and 8.6, $P<0.02$,

218 Supplementary Tables S3 and S5).

219 Landscape richness decreased the biomass of epigeic species ( $F=4.9, P=0.041$, Supplementary

220 Table S4) but enhanced the epi-anecic species richness $(F=6.6, P=0.019$, Supplementary Table S4). The

221 increase of SHDI decreased the total earthworm abundance $(F=4.6, P=0.047$, Table 1$)$. In addition, the

222 increase in plant diversity was positively correlated to Shannon diversity index and species evenness $(F=$ $223 \quad 5.0$ and $4.8, P<0.04$, Table 1$)$.

224 Interestingly, the abundance of strict-anecic species, their biomass and richness were not affected 225 by any of the environmental filters measured (Supplementary Tables S3, S4 and S5).

\section{Impact of hedgerow presence on earthworm communities}

Over the 3 grasslands oversampled, earthworm abundance was higher in the 2-year-old grassland (834 \pm 76 individuals. $\mathrm{m}^{-2}$ ) compared to the 1-year-old (306 \pm 32 individuals. $\mathrm{m}^{-2}$ ) and 7-year-old grasslands

230 (385 \pm 32 individuals. $\left.\mathrm{m}^{-2}\right)$. Earthworm species richness was higher in the 2- and 7-year-old grasslands (11.0

$231 \pm 0.4$ and $10.2 \pm 0.3$, respectively) compared to the 1-year-old grassland (7.9 \pm 0.4$)$. Earthworm species 232 composition was also strongly different between these three grasslands. For example, the presence of 233 Eisenia tetraedra occurred only in the 2-year-old grassland and the presence of Aporrectodea caliginosa 234 meridionalis occurred only in the 7-year-old grassland.

235 Earthworm species richness was $21.0 \%$ and $23.2 \%$ higher with the presence of a hedgerow, 236 compared to the presence of a ditch, in the grasslands of 1 - and 2-year-old $(t=5.8$ and 13.9, $P<0.03$, Fig. $2373 \mathrm{a}$ and $\mathrm{b}$ ). It was however not affected in the 7-year-old grassland ( $t=0.0, P=0.85$, Fig. $3 \mathrm{c})$. The abundance 238 of earthworms was not affected by the presence of hedgerows in the three selected grasslands ( $t=0.0$ to $2390.03, P>0.865)$.

$240 \quad$ Overall, except Allolobophora icterica and Aporrectodea nocturna that were more abundant with 241 the presence of a hedgerow, the strict-anecic and endogeic species were evenly distributed between the plots 242 with and without a hedgerow. The distribution of epi-anecic earthworm species was heterogeneous, but 243 Lumbricus rubellus rubellus and Lumbricus terrestris were more often observed in presence of a hedgerow. 244 The distribution of epigeic earthworm was species dependent: Dendrobaena mammalis occurrence was 245 higher in presence of a hedgerow and Eisenia tetraedra was observed in presence of a hedgerow in the 2- 
year-old grassland only. Lumbricus castaneus and Lumbricus rubellus castanoïdes occurrences were overall similar between the plots, independent from the presence of a hedgerow.

In the present study, we clearly demonstrated that soil properties, grassland management and landscape diversity conjointly affected the selected parameters of the earthworm communities. Our findings hence contrast with those of Frazão et al. (2017) who reported that earthworm communities of the croplands were impacted by agricultural practices only but neither by soil properties nor landscape diversity.

Contrary to previous studies that observed an effect of soil properties at the regional scale (Decaëns et al., 2003; Vanbergen et al., 2007; Decaëns et al., 2008), here, by taking the earthworm ecological category into account, we evidenced that soil properties impact on a finer scale (i.e. $10 \mathrm{~km}^{2}$ ), the abundance, biomass and richness of earthworm ecological categories. This result might be due to the strong spatial heterogeneity of the soil properties in the studied region (Jamagne, 2011). In agreement with previous studies, we observed that higher soil sand content decreased the total abundance of earthworms (Hendrix et al., 1992; Lapied et al., 2009), which could be due to the low capacity of sandy soils to hold water, leading to an unfavorable habitat for earthworms (Lee, 1985). In addition, the increase in soil $\mathrm{pH}$ was positively correlated to both earthworm species richness (Joschko et al., 2006) and total abundance (Ma et al., 1990; McCallum et al., 2016). Nonetheless, several reviews observed that earthworm preference to soil $\mathrm{pH}$ was species-dependent due to their synecology (Bouché, 1972; Edwards and Lofty, 1977; Lee, 1985) but the underlying mechanisms for $\mathrm{pH}$ preference are not fully understood yet. In line with their feeding behaviour that consists in consuming mainly humified organic matter, endogeic earthworm communities were more abundant and diversified in grasslands presenting high contents of soil organic matter (Bouché, 1977; Piearce, 1978; Ferrière, 1980).

Regarding grassland management, increasing livestock unit was the most damaging factor for earthworm communities as it decreased the total biomass, species richness, the Shannon diversity index and the species evenness. This strong negative effect could be associated to the trampling at high stocking levels that damages soil structure and thus adversely affect earthworm communities and burrows (Cluzeau et al., 1992; Pietola et al., 2005; Chan and Barchia, 2007). Interestingly, earthworms' response to livestock unit was almost entirely confined to the largest epi-anecic and endogeic species and only the earthworm biomass was affected, contrary to their abundance, suggesting a decrease in the mean body size rather than in individuals' number. Surprisingly, mineral fertilisation enhanced the abundance and biomass of epigeic species, but this finding is nonetheless in line with some previous studies that reported an increase in earthworm abundance in relation to $\mathrm{N}$ mineral fertilisation (Muldowney et al., 2003; King and Hutchinson, 
2007; Curry et al., 2008). Mineral fertilisation would probably allow a better primary production leading to higher leaf litter inputs that constitute a source of refuge and food for earthworms. Further studies are needed, in grassland, to elaborate the different impacts of manure versus mineral fertilisation on earthworms. Overall, we observed that within grasslands, grazing pressure led to smaller and less-diversified earthworm communities.

We observed a negative effect of increasing landscape diversity (richness and Shannon Index) on the total abundance of earthworms and, to our knowledge, for the first time, the biomass of epigeic earthworms in grasslands. A negative correlation between the total abundance of earthworms and landscape diversity was also observed by Flohre et al., (2011) in croplands, and the authors hypothesized that landscape diversity increases the number of earthworm predators. Indeed, several studies highlighted that landscape diversity enhance the abundances of invertebrates, mammals and birds (Marshall and Moonen, 2002; Maudsley et al., 2002; Vickery et al., 2009) that are potential predators for earthworms (Granval and Aliaga, 1988; O’Brien et al., 2016). We can also hypothesize that the capacity of epigeic species to disperse is hindered by physical barriers (i.e. hedge or ditch) and different soil properties (shelter and litter availability) in neighboring habitats that nonetheless constitute landscape diversity. In contrast, the species richness of epi-anecic earthworm was enhanced by the landscape diversity. As epi-anecic earthworm species have a great mobility varying from 1.5 to 14 m. year ${ }^{-1}$ (Hoogerkamp et al., 1983; Eijsackers, 2011; Nuutinen et al., 2014) and the ability to burrow into the soil to protect themselves, higher landscape diversity around grasslands could enhance their areas of emigration. Endogeic earthworm species were not impacted by landscape diversity and were highly abundant in each grassland as previously reported (Lavelle, 1983; Decaëns et al., 2008). Overall, it is possible that low agricultural practices in grasslands, compared to croplands or vineyard, could increase the effect of the surrounding landscape diversity on earthworm communities (Roarty and Schmidt, 2013; Buchholz et al., 2017; Frazão et al., 2017). surrounding grasslands. Hedgerows especially acted in young grasslands (i.e. 1- and 2-year-old grassland), which is probably due to the increase earthworm species aggregation with the age of the grasslands (Richard et al., 2012). It is well known that hedgerows locally modify soil properties (i.e. soil moisture, temperature or organic matter content; Marshall and Moonen, 2002), and especially the amount and type of litter deposited at the soil surface (Walter et al., 2003). This litter input is a key factor for the development of earthworm communities (Lee, 1985; Edwards, 2004), and in particular for epigeic and epi-anecic species that have a diet mainly composed of fresh leaf litter (Bouché and Kretzschmar, 1974; Piearce, 1978; Ferrière, 1980). In field, earthworm communities living in grasslands surrounded by a hedgerow were richer in earthworm species compared to earthworm communities in grasslands surrounded by a ditch, especially for 
312 epigeic and epi-anecic earthworm species. Thus, hedgerows presence could promote earthworm diversity 313 in grasslands. Increasing epi-anecic earthworm diversity in grasslands landscape could have consequences 314 on ecosystem services provided by these species. Hoeffner et al. (2018) observed that burrows' fungal 315 communities were regulated by epi-anecic species identity, which could increase the diversity of the 316 drilospheric microbiota and improve soil functioning. Besides, as it is difficult to monitor the earthworm 317 diversity response to global change drivers, earthworm databases often concern surveys carried out at 318 regional or national scales (Rutgers et al., 2009; Cluzeau et al., 2012; Cameron et al., 2016). A first 319 predictive model on the abundance and diversity of earthworms was created by Rutgers et al. (2016) taking 320 into account soil occupation and properties. Future predictive models could therefore take into account the 321 landscape as an additional factor regulating these earthworm communities.

\section{CONCLUSION}

Our study clearly illustrated that earthworm communities in grasslands were affected by the three environmental filters considered: soil properties, grassland management and landscape diversity. Soil properties was the main environmental filter controlling earthworm communities. However, we also highlighted important effects of grassland management, for instance a strong decrease in abundance of earthworms with increasing livestock unit. We observed various effects of landscape diversity, such as a surprising overall decrease of earthworm abundance or a higher epi-anecic richness in diverse landscapes.

330 Therefore, our findings demonstrated conjoint effects of various environmental filters as drivers of 331 earthworm communities. Taken together, our results suggest a strong context dependency in the assembly 332 rules of earthworm communities, despite the fact that these communities are well known to be ubiquitous 333 and resilient.

\section{ACKNOWLEDGEMENTS}

We thank the LABOCEA (Combourg, France) for mineral soil analyses and Météo France for meteorological data. We also thank Sarah Guillocheau, Daniel Cylly, Albin Fertil, André Bastin, Valentin

338 Tripet, Olivier Jambon, Stéphanie Llopis, Cendrine Mony and Vincent Jung for their help during field 339 sampling. We sincerely thank Claudia Wiegand for helpful comments and improvement of the English. 340 Kevin Hoeffner and Lou Barbe were supported by a French PhD grant from the French Ministère de la 341 Recherche. 
Bardgett, R., Hopkins, D., Usher, M., 2005. Biological diversity and function in soils. Cambridge University Press, Cambridge.

Bar-On, Y.M., Phillips, R., Milo, R., 2018. The biomass distribution on Earth. Proceedings of the National Academy of Sciences 201711842.

Baudry, J., Burel, F., Thenail, C., Le Cœur, D., 2000. A holistic landscape ecological study of the interactions between farming activities and ecological patterns in Brittany, France. Landscape and Urban Planning 50, 119-128.

Bertrand, M., Barot, S., Blouin, M., Whalen, J., Oliveira, T. de, Roger-Estrade, J., 2015. Earthworm services for cropping systems. A review. Agronomy for Sustainable Development 35, 553-567.

Blouin, M., Hodson, M.E., Delgado, E.A., Baker, G., Brussaard, L., Butt, K.R., Dai, J., Dendooven, L., Peres, G., Tondoh, J.E., Cluzeau, D., Brun, J.-J., 2013. A review of earthworm impact on soil function and ecosystem services: Earthworm impact on ecosystem services. European Journal of Soil Science 64, 161-182.

Boag, B., Palmer, L.F., Neilson, R., Legg, R., Chambers, S.J., 1997. Distribution, prevalence and intensity of earthworm populations in arable land and grassland in Scotland. Annals of Applied Biology 130, 153-165.

Bouché, M.B., 1977. Strategies lombriciennes. Ecological Bulletins, Soil Organisms as Components of Ecosystems 25, 122-132.

Bouché, M.B., 1972. Lombriciens de France: écologie et systématique, INRA-Annales de Zoologie Ecologie Animale. ed. INRA, France.

Bouché, M.B., Kretzschmar, A., 1974. Fonctions des lombriciens II. Recherches méthodologiques pour l’analyse qualitative de la matière organique végétale ingéré (étude du peuplement de la station RCP-165/PBI). Revue d'Ecologie et de Biologie Du Sol 11, 127-139.

Briones, M.J.I., Schmidt, O., 2017. Conventional tillage decreases the abundance and biomass of earthworms and alters their community structure in a global meta-analysis. Global Change Biology 23, 4396-4419.

Buchholz, J., Querner, P., Paredes, D., Bauer, T., Strauss, P., Guernion, M., Scimia, J., Cluzeau, D., Burel, F., Kratschmer, S., Winter, S., Potthoff, M., Zaller, J.G., 2017. Soil biota in vineyards are more influenced by plants and soil quality than by tillage intensity or the surrounding landscape. Scientific Reports 7, 17445.

Butt, K.R., Frederickson, J., Morris, R.M., 1994. Effect of earthworm density on the growth and reproduction. Pedobiologia 38, 254-261. 
Cameron, E.K., Vila, M., Cabeza, M., 2016. Global meta-analysis of the impacts of terrestrial invertebrate invaders on species, communities and ecosystems. Global Ecology and Biogeography 25, 596-606.

Chan, K.Y., 2001. An overview of some tillage impacts on earthworm population abundance and diversity - Implications for functioning in soils. Soil and Tillage Research 57, 179-191.

Chan, K.Y., Barchia, I., 2007. Soil compaction controls the abundance, biomass and distribution of earthworms in a single dairy farm in south-eastern Australia. Soil and Tillage Research 94, 75-82.

Cluzeau, D., Binet, F., Vertes, F., Simon, J.C., Riviere, J.M., Trehen, P., 1992. Effects of intensive cattle trampling on soil-plant-earthworms system in two grassland types. Soil Biology and Biochemistry 24, 1661-1665.

Cluzeau, D., Guernion, M., Chaussod, R., Martin-Laurent, F., Villenave, C., Cortet, J., Ruiz-Camacho, N., Pernin, C., Mateille, T., Philippot, L., Bellido, A., Rougé, L., Arrouays, D., Bispo, A., Pérès, G., 2012. Integration of biodiversity in soil quality monitoring: Baselines for microbial and soil fauna parameters for different land-use types. European Journal of Soil Biology, Bioindication in Soil Ecosystems 49, 63-72.

Conant, R.T., Paustian, K., 2002. Potential soil carbon sequestration in overgrazed grassland ecosystems. Global Biogeochemical Cycles 16, 90-1-90-9.

Costanza, R., d’Arge, R., Groot, R. de, Farber, S., Grasso, M., Hannon, B., Limburg, K., Naeem, S., O’Neill, R.V., Paruelo, J., Raskin, R.G., Sutton, P., Belt, M. van den, 1997. The value of the world's ecosystem services and natural capital. Nature 387, 253-260.

Crawley, M.J., 2012. The R Book, 2nd Edition. ed. Wiley \& Sons, Chichester.

Crittenden, S.J., Huerta, E., de Goede, R.G.M., Pulleman, M.M., 2015. Earthworm assemblages as affected by field margin strips and tillage intensity: An on-farm approach. European Journal of Soil Biology 66, 49-56.

Curry, J.P., 2004. Factors affecting the abundance of earthworms in soils, in: Edwards, C.A. (Ed.), Earthworm Ecology. CRC Press, Boca Raton, pp. 91-113.

Curry, J.P., Doherty, P., Purvis, G., Schmidt, O., 2008. Relationships between earthworm populations and management intensity in cattle-grazed pastures in Ireland. Applied Soil Ecology 39, 58-64.

Decaëns, T., Bureau, F., Margerie, P., 2003. Earthworm communities in a wet agricultural landscape of the Seine Valley (Upper Normandy, France). Pedobiologia, The 7th International Symposium on Earthworm Ecology 47, 479-489.

Decaëns, T., Margerie, P., Aubert, M., Hedde, M., Bureau, F., 2008. Assembly rules within earthworm communities in North-Western France - A regional analysis. Applied Soil Ecology 39, 321-335. 
Edwards, C.A., 2004. The importance of earthworms as key representatives of the soil fauna, in: Edwards, C.A. (Ed.), Earthworm Ecology. CRC Press, Boca Raton, pp. 3-11.

Edwards, C.A., Lofty, J.R., 1977. Biology of Earthworms, 2nd ed. Wiley \& Sons, New York.

Eijsackers, H., 2011. Earthworms as colonizers of natural and cultivated soil environments. Applied Soil Ecology 50, 1-13.

Eijsackers, H., 2010. Earthworms as colonisers: Primary colonisation of contaminated land, and sediment and soil waste deposits. Science of The Total Environment 408, 1759-1769.

Ferrière, G., 1980. Fonctions des Lombriciens. VII. Une méthode d’analyse de la matière organique végétale ingérée. Pedobiologia 20, 263-273.

Flohre, A., Rudnick, M., Traser, G., Tscharntke, T., Eggers, T., 2011. Does soil biota benefit from organic farming in complex vs. simple landscapes? Agriculture, Ecosystems \& Environment 141, 210-214.

Frazão, J., de Goede, R.G.M., Brussaard, L., Faber, J.H., Groot, J.C.J., Pulleman, M.M., 2017. Earthworm communities in arable fields and restored field margins, as related to management practices and surrounding landscape diversity. Agriculture, Ecosystems \& Environment 248, 1-8.

Granval, P., Aliaga, R., 1988. Analyse critique des connaissances sur les prédateurs de lombriciens. Gibier Faune Sauvage 5, 71-94.

Groenigen, J.W. van, Lubbers, I.M., Vos, H.M.J., Brown, G.G., Deyn, G.B.D., Groenigen, K.J. van, 2014. Earthworms increase plant production: a meta-analysis. Scientific Reports 4, 6365.

Hartenstein, R., 1984. Rate of production and loss of earthworm biomass in relation to species and size. Soil Biology and Biochemistry 16, 643-649.

Hartenstein, R., Amico, L., 1983. Production and carrying capacity for the earthworm Lumbricus terrestris in culture. Soil Biology and Biochemistry 15, 51-54.

Hendrix, P.F., Mueller, B.R., Bruce, R.R., Langdale, G.W., Parmelee, R.W., 1992. Abundance and distribution of earthworms in relation to landscape factors on the Georgia Piedmont, U.S.A. Soil Biology and Biochemistry 24, 1357-1361.

Hoeffner, K., Monard, C., Santonja, M., Cluzeau, D., 2018. Feeding behaviour of epi-anecic earthworm species and their impacts on soil microbial communities. Soil Biology and Biochemistry 125, 1-9.

Hoeffner, K., Santonja, M., Cluzeau, D., Monard, C., 2019. Epi-anecic rather than strict-anecic earthworms enhance soil enzymatic activities. Soil Biology and Biochemistry 132, 93-100.

Hole, F.D., 1981. Effects of animals on soil. Geoderma 25, 75-112.

Hoogerkamp, M., Rogaar, H., Eijsackers, H.J.P., 1983. Effect of earthworms on grassland on recently reclaimed polder soils in the Netherlands, in: Satchell, J.E. (Ed.), Earthworm Ecology - from Darwin to Vermiculture. Chapman and Hall, London, pp. 85-105. 
441

442

443

444

445

446

447

448

449

450

451

452

453

454

455

456

457

458

459

460

461

462

463

464

465

466

467

468

469

470

471

472

473

IUSS Working Group, W.R.B., 2015. World Reference Base for Soil Resources 2014, update 2015. International soil classification system for naming soils and creating legends for soil maps. (No. 106), World Soil Resources Reports. FAO, Rome.

Jamagne, M., 2011. Grands paysages pédologiques de France, 1st ed. Editions QUAE GIE, Versailles.

Jégou, D., Cluzeau, D., Balesdent, J., Trehen, P., 1998. Effects of four ecological categories of earthworms on carbon transfer in soil. Applied Soil Ecology 9, 249-255.

Joschko, M., Fox, C.A., Lentzsch, P., Kiesel, J., Hierold, W., Krück, S., Timmer, J., 2006. Spatial analysis of earthworm biodiversity at the regional scale. Agriculture, Ecosystems \& Environment 112, 367380.

King, K.L., Hutchinson, K.J., 2007. Pasture and grazing land: assessment of sustainability using invertebrate bioindicators. Australian Journal of Experimental Agriculture 47, 392-403.

Kovács-Hostyánszki, A., Elek, Z., Balázs, K., Centeri, C., Falusi, E., Jeanneret, P., Penksza, K., Podmaniczky, L., Szalkovszki, O., Báldi, A., 2013. Earthworms, spiders and bees as indicators of habitat quality and management in a low-input farming region-A whole farm approach. Ecological Indicators, Biodiversity Monitoring 33, 111-120.

Lapied, E., Nahmani, J., Rousseau, G.X., 2009. Influence of texture and amendments on soil properties and earthworm communities. Applied Soil Ecology 43, 241-249.

Larsen, T., Pollierer, M.M., Holmstrup, M., D’Annibale, A., Maraldo, K., Andersen, N., Eriksen, J., 2016. Substantial nutritional contribution of bacterial amino acids to earthworms and enchytraeids: A case study from organic grasslands. Soil Biology and Biochemistry 99, 21-27.

Lavelle, P., 1983. The structure of earthworm communities, in: Satchell, J.E. (Ed.), Earthworm Ecology from Darwin to Vermiculture. Chapman and Hall, London, pp. 449-466.

Lee, K.E., 1985. Earthworms - Their ecology and relationships with soils and land use. Academic Press, Sydney.

Lüscher, G., Jeanneret, P., Schneider, M.K., Turnbull, L.A., Arndorfer, M., Balázs, K., Báldi, A., Bailey, D., Bernhardt, K.G., Choisis, J.-P., Elek, Z., Frank, T., Friedel, J.K., Kainz, M., KovácsHostyánszki, A., Oschatz, M.-L., Paoletti, M.G., Papaja-Hülsbergen, S., Sarthou, J.-P., Siebrecht, N., Wolfrum, S., Herzog, F., 2014. Responses of plants, earthworms, spiders and bees to geographic location, agricultural management and surrounding landscape in European arable fields. Agriculture, Ecosystems \& Environment 186, 124-134.

Ma, W.-C., Brussaard, L., de Ridder, J.A., 1990. Long-term effects of nitrogenous fertilizers on grassland earthworms (Oligochaeta: Lumbricidae): Their relation to soil acidification. Agriculture, Ecosystems \& Environment 30, 71-80. 
Marshall, E.J.P., Moonen, A.C., 2002. Field margins in northern Europe: their functions and interactions with agriculture. Agriculture, Ecosystems \& Environment, The Ecology of Field Margins in European Farming Systems 89, 5-21.

Maudsley, M., Seeley, B., Lewis, O., 2002. Spatial distribution patterns of predatory arthropods within an English hedgerow in early winter in relation to habitat variables. Agriculture, Ecosystems \& Environment, The Ecology of Field Margins in European Farming Systems 89, 77-89.

McCallum, H.M., Wilson, J.D., Beaumont, D., Sheldon, R., O’Brien, M.G., Park, K.J., 2016. A role for liming as a conservation intervention? Earthworm abundance is associated with higher soil $\mathrm{pH}$ and foraging activity of a threatened shorebird in upland grasslands. Agriculture Ecosystems \& Environment 223, 182-189.

Michon, J., 1954. Contribution expérimentale à l'étude de la biologie des Lumbricidae. Les variations pondérales au cours des différentes modalités du développement postembryonnaire. Poitiers University, Poitiers.

Muldowney, J., Curry, J.P., O’Keeffe, J., Schmidt, O., 2003. Relationships between earthworm populations, grassland management and badger densities in County Kilkenny, Ireland. Pedobiologia, The 7th International Symposium on Earthworm Ecology 47, 913-919.

Neuhauser, E.F., Hartenstein, R., Kaplan, D.L., 1980. Growth of the earthworm Eisenia foetida in relation to population density and food rationing. Oikos 35, 93-98.

Nuutinen, V., Butt, K.R., Jauhiainen, L., Shipitalo, M.J., Sirén, T., 2014. Dew-worms in white nights: Highlatitude light constrains earthworm (Lumbricus terrestris) behaviour at the soil surface. Soil Biology and Biochemistry 72, 66-74.

O’Brien, J., Elliott, S., Hayden, T.J., 2016. Use of hedgerows as a key element of badger (Meles meles) behaviour in Ireland. Mammalian Biology 81, 104-110.

Pelosi, C., Barot, S., Capowiez, Y., Hedde, M., Vandenbulcke, F., 2014. Pesticides and earthworms. A review. Agronomy for Sustainable Development 34, 199-228.

Piearce, T.G., 1978. Gut contents of some lumbricid earthworms. Pedobiologia 18, 153-157.

Pietola, L., Horn, R., Yli-Halla, M., 2005. Effects of trampling by cattle on the hydraulic and mechanical properties of soil. Soil and Tillage Research 82, 99-108.

Ponge, J.F., Pérès, G., Guernion, M., Ruiz-Camacho, N., Cortet, J., Pernin, C., Villenave, C., Chaussod, R., Martin-Laurent, F., Bispo, A., Cluzeau, D., 2013. The impact of agricultural practices on soil biota: A regional study. Soil Biology and Biochemistry 67, 271-284.

R. Core Team, 2017. R: A language and environment for statistical computing. R foundation for statistical computing, Vienna, Austria. 
Richard, B., Legras, M., Margerie, P., Mathieu, J., Barot, S., Caro, G., Desjardins, T., Dubs, F., Dupont, L., Decaëns, T., 2012. Spatial organization of earthworm assemblages in pastures of northwestern France. European Journal of Soil Biology 53, 62-69.

Roarty, S., Schmidt, O., 2013. Permanent and new arable field margins support large earthworm communities but do not increase in-field populations. Agriculture, Ecosystems \& Environment 170, 45-55.

Rutgers, M., Orgiazzi, A., Gardi, C., Römbke, J., Jänsch, S., Keith, A.M., Neilson, R., Boag, B., Schmidt, O., Murchie, A.K., Blackshaw, R.P., Pérès, G., Cluzeau, D., Guernion, M., Briones, M.J.I., Rodeiro, J., Piñeiro, R., Cosín, D.J.D., Sousa, J.P., Suhadolc, M., Kos, I., Krogh, P.-H., Faber, J.H., Mulder, C., Bogte, J.J., Wijnen, H.J. va., Schouten, A.J., Zwart, D. de, 2016. Mapping earthworm communities in Europe. Applied Soil Ecology 97, 98-111.

Rutgers, M., Schouten, A.J., Bloem, J., Eekeren, N.V., Goede, R.G.M.D., Akkerhuis, G.A.J.M.J., Wal, A.V. der, Mulder, C., Brussaard, L., Breure, A.M., 2009. Biological measurements in a nationwide soil monitoring network. European Journal of Soil Science 60, 820-832.

Smith, J., Potts, S.G., Woodcock, B.A., Eggleton, P., 2008. Can arable field margins be managed to enhance their biodiversity, conservation and functional value for soil macrofauna? Journal of Applied Ecology 45, 269-278.

Tews, J., Brose, U., Grimm, V., Tielbörger, K., Wichmann, M.C., Schwager, M., Jeltsch, F., 2004. Animal species diversity driven by habitat heterogeneity/diversity: the importance of keystone structures. Journal of Biogeography 31, 79-92.

Thomas, Z., Abbott, B.W., Troccaz, O., Baudry, J., Pinay, G., 2016. Proximate and ultimate controls on carbon and nutrient dynamics of small agricultural catchments. Biogeosciences 13, 1863-1875.

Vanbergen, A.J., Watt, A.D., Mitchell, R., Truscott, A.-M., Palmer, S.C.F., Ivits, E., Eggleton, P., Jones, T.H., Sousa, J.P., 2007. Scale-specific correlations between habitat heterogeneity and soil fauna diversity along a landscape structure gradient. Oecologia 153, 713-725.

Vickery, J.A., Feber, R.E., Fuller, R.J., 2009. Arable field margins managed for biodiversity conservation: A review of food resource provision for farmland birds. Agriculture, Ecosystems \& Environment 133, 1-13.

Vršic, S., 2011. Soil erosion and earthworm population responses to soil management systems in steepslope vineyards. Plant Soil Environ 57, 258-263.

Walter, C., Merot, P., Layer, B., Dutin, G., 2003. The effect of hedgerows on soil organic carbon storage in hillslopes. Soil Use and Management 19, 201-207. 
539 Werling, B.P., Dickson, T.L., Isaacs, R., Gaines, H., Gratton, C., Gross, K.L., Liere, H., Malmstrom, C.M., Meehan, T.D., Ruan, L., Robertson, B.A., Robertson, G.P., Schmidt, T.M., Schrotenboer, A.C., Teal, T.K., Wilson, J.K., Landis, D.A., 2014. Perennial grasslands enhance biodiversity and multiple ecosystem services in bioenergy landscapes. Proceedings of the National Academy of Sciences 111, 1652-1657.

544 Zaller, J.G., Arnone, J.A., 1999. Earthworm responses to plant species' loss and elevated CO2 in calcareous 545 grassland. Plant and Soil 208, 1-8.

546

547 


\section{TABLES}

549 on total earthworm abundance, total biomass, species richness and Shannon diversity index and evenness index (when VIF $>5$ ). Fvalues and associated $P$-values are indicated. Significant $P$-values are indicated in bold $(\mathrm{P}<0.05)$. $\mathrm{df}=$ degrees of freedom, $\% \mathrm{SS}=$ percentage of sum of square.

\begin{tabular}{|c|c|c|c|c|c|c|c|c|c|c|c|c|c|c|c|c|c|c|c|c|}
\hline & \multicolumn{4}{|c|}{ Total abundance } & \multicolumn{4}{|c|}{ Total biomass } & \multicolumn{4}{|c|}{ Total richness } & \multicolumn{4}{|c|}{ Shannon } & \multicolumn{4}{|c|}{ Equitability } \\
\hline & $\mathrm{df}$ & $\% \mathrm{SS}$ & $F$ & $P$ & $\mathrm{df}$ & $\% \mathrm{SS}$ & $F$ & $P$ & $\mathrm{df}$ & $\%$ SS & $F$ & $P$ & $\mathrm{df}$ & $\% \mathrm{SS}$ & $F$ & $P$ & df & $\% \mathrm{SS}$ & $F$ & $P$ \\
\hline \multicolumn{21}{|l|}{ Soil properties } \\
\hline Clay content & 1 & 5.9 & 2.2 & 0.157 & & & & & & & & & & & & & & & & \\
\hline Sand content & 1 & 5.2 & 1.9 & 0.182 & 1 & 0.4 & 0.1 & 0.711 & 1 & 0.1 & 0.0 & 0.841 & & & & & & & & \\
\hline Organic matter content & 1 & 14.4 & 5.3 & 0.033 & 1 & 6.0 & 2.1 & 0.164 & & & & & & & & & & & & \\
\hline $\mathrm{pH}$ & 1 & 13.4 & 5.0 & 0.039 & 1 & 19.4 & 6.8 & 0.018 & & & & & & & & & & & & \\
\hline \multicolumn{21}{|c|}{ Grassland management } \\
\hline Grassland age & & & & & & & & & & & & & 1 & 7.5 & 9.9 & 0.107 & 1 & 7.3 & 2.4 & 0.141 \\
\hline Livestock unit & & & & & 1 & 16.3 & 5.7 & 0.028 & 1 & 31.3 & 9.6 & 0.005 & 1 & 26.2 & 2.8 & 0.005 & 1 & 15.1 & 4.8 & 0.040 \\
\hline \multicolumn{21}{|l|}{ Fertilisation } \\
\hline \multicolumn{21}{|l|}{ Landscape diversity } \\
\hline \multicolumn{21}{|l|}{ Landscape Richness } \\
\hline SHDI & 1 & 12.3 & 4.6 & 0.047 & 1 & 6.4 & 2.2 & 0.153 & & & & & & & & & & & & \\
\hline Plant diversity & & & & & & & & & & & & & 1 & 13.2 & 5.0 & 0.037 & 1 & 15.1 & 4.8 & 0.040 \\
\hline Residuals & 18 & 48.7 & & & 18 & 51.5 & & & 21 & 68.6 & & & 20 & 53.1 & & & 20 & 62.5 & & \\
\hline
\end{tabular}


Fig. 1. Relationship between total earthworm biomass and soil $\mathrm{pH} . \mathrm{R}^{2}$ and associated $P$-value of the linear regression are indicated.

Fig. 2. Relationships between livestock unit and (a) anecic earthworm abundance, (b) epi-anecic earthworm abundance and (c) Shannon index. $\mathrm{R}^{2}$ and associated $P$-values of linear regressions are

563

564 indicated.

Fig. 3. Earthworm species richness in plots with a hedgerow or with a ditch (i.e. control plot without 566 hedgerow) for grassland of (a) 1-year-old, (b) 2-year-old and (c) 7-year-old. Values are means \pm $\mathrm{SD} ; \mathrm{n}=3$. Different letters denote significant differences between the two plots with $\mathrm{a}>\mathrm{b}$ (post 
Fig. 1.

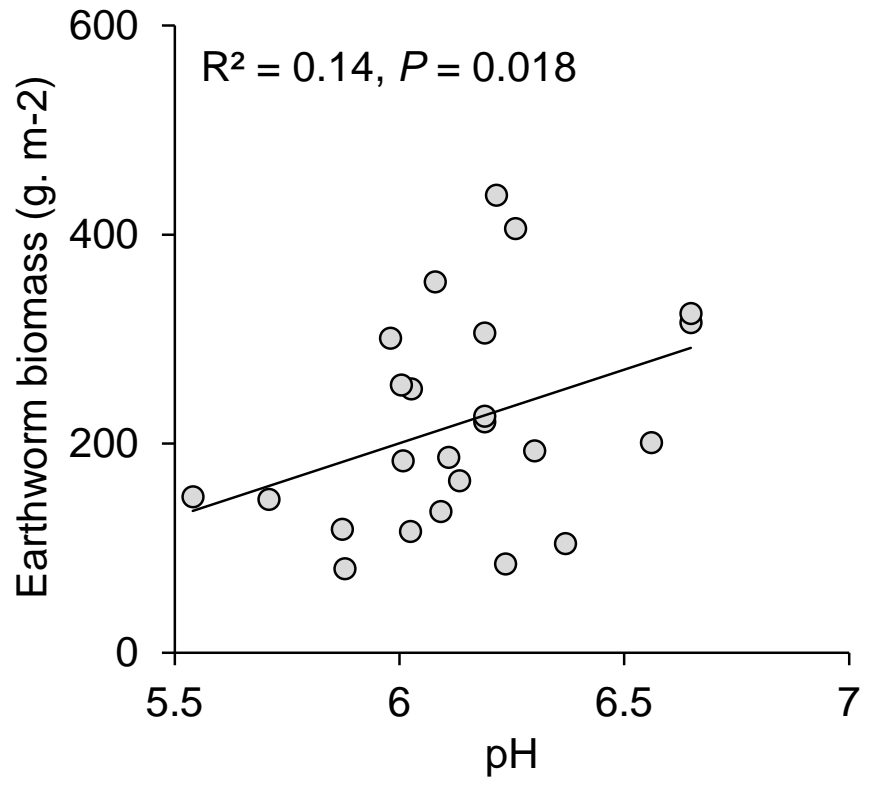

571

572 
$573 \quad$ Fig. 2.

574
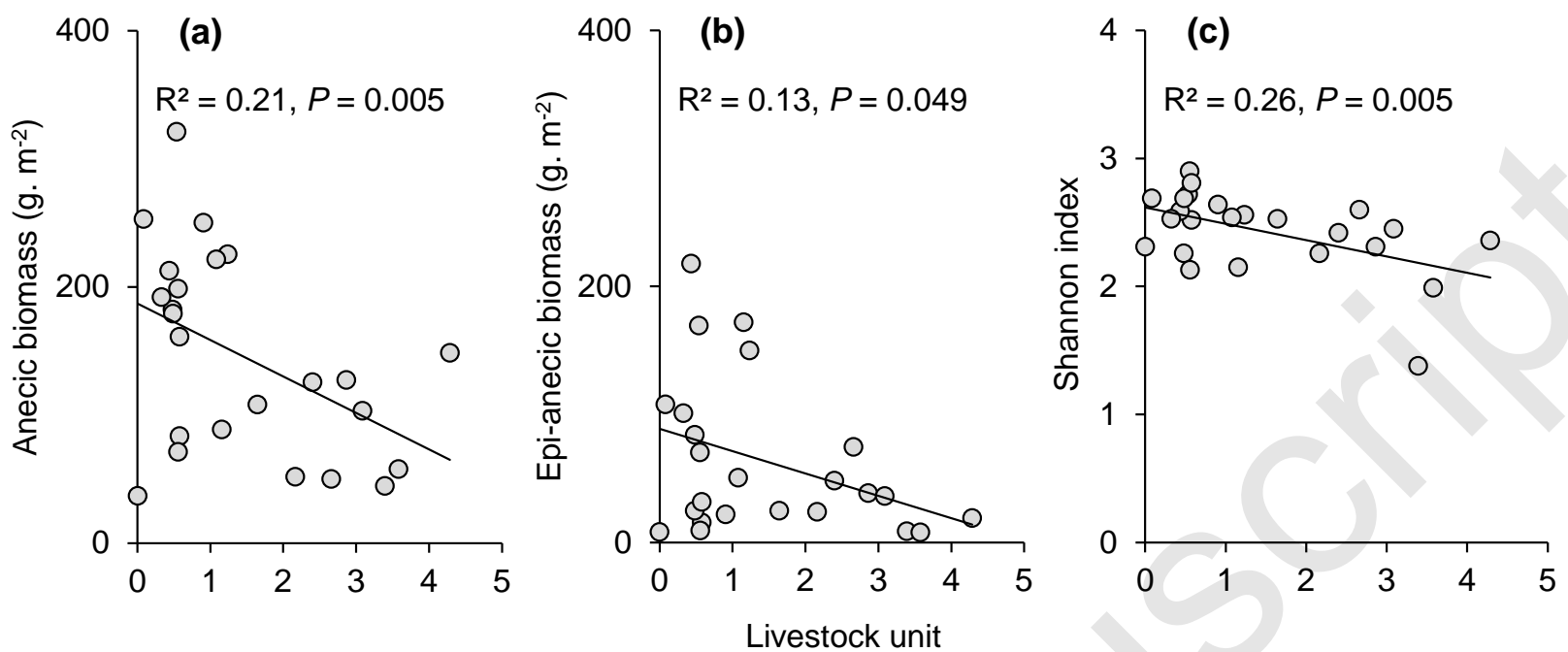

575

576 
$577 \quad$ Fig. 3.

Endogeic $\square$ Strict-anecic $\square$ Epi-anecic $\square$ Epigeic

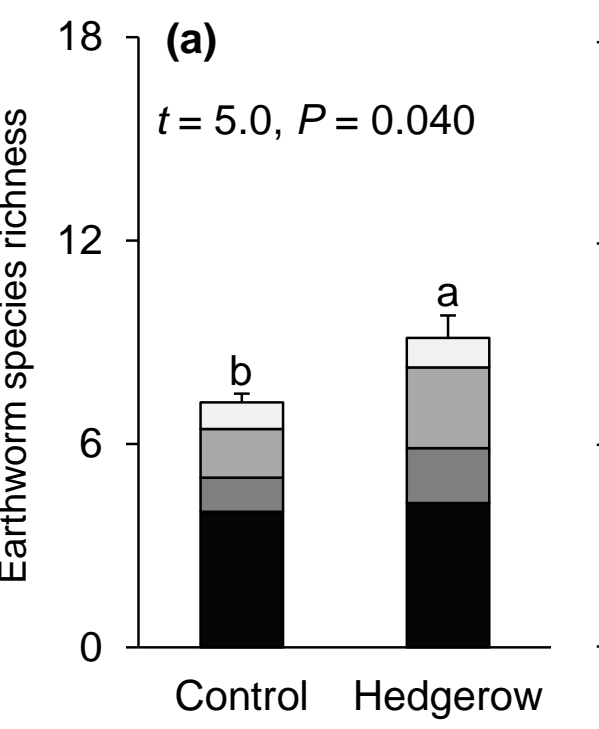

(b)

$t=26.8, P<0.001$

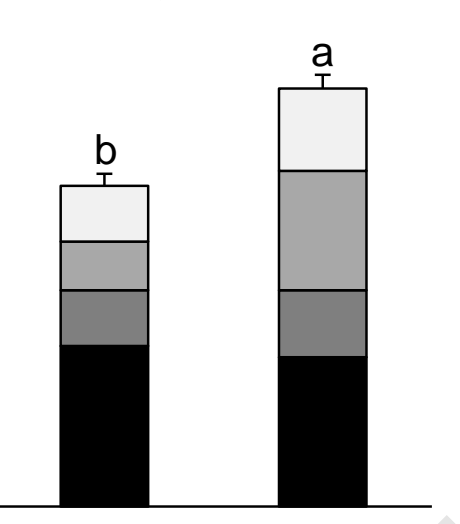

Control Hedgerow (c)

$t=0.0, P=0.851$

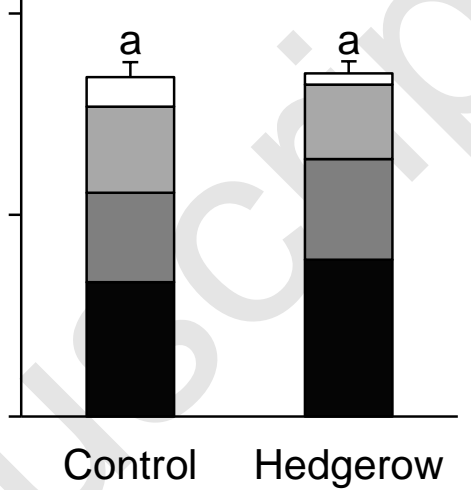

